\title{
Peertechz
}

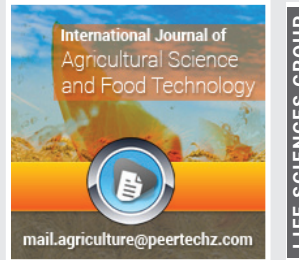

\section{Dynamics of value chain in climate resilient vegetable production practices}

\section{Ujjal Raj Acharya ${ }^{1 *}$ and Krishna Prasad Pant ${ }^{2}$}

${ }^{1}$ Research Scholar, Central Department of Economics; Tribhuvan University, Kathmandu, Nepal

${ }^{2}$ Visiting Faculty, Central Department of Economics, Tribhuvan University, Kathmandu, Nepal
Received: 09 January, 2021

Accepted: 15 February, 2021

Published: 17 February, 2021

*Corresponding author: Ujjal Raj Acharya, Research Scholar, Central Department of Economics; Tribhuvan University, Kathmandu, Nepal,

E-mail: uacharya25@gmail.com

Keywords: Value chain analysis; Vegetable farming; Climate resilient practices; Himalica project; Smallholders; Coping strategies

https://www.peertechz.com

Check for updates

\begin{abstract}
Climate resilient practices in farming is an integrated process that reduces risks in production and marketing. This study introduced an integrated package of climate resilient practices in vegetable farming to cope with climate change and related problems. The study that was carried out in Udayapur district of Nepal and it analyzed application of climate resilient practices in value chain of vegetable farming. The data were obtained from Himalica pilot project initiated by International Centre for Integrated Mountain Development (ICIMOD) which surveyed 300 vegetable farm households using a semi-structured questionnaire. In addition, a checklist was used for Focus Group Discussions (FGDs) with farmers' groups. The collected data were coded and entered into Microsoft Excel and descriptive statistics such as frequency, percentage and mean were calculated. For the analysis of costs, revenue and profitability, simple accounting method was used. The study shows that profit of farmers depends on the market type and farmers revenue increases when they sell their produce through farmers' co-operatives. Farmers need irrigation water, material supports, technology as well as organized farmers' group in order to increase the profit and to mitigate the risk from climate change and climate variability. The study found that climate resilient practices in vegetable value chain benefits farmers in terms of social, economic and environmental aspects.
\end{abstract}

\section{Background of the study}

Agriculture is the most important sector of Nepalese Economy and is central to the survival of millions of people especially in rural areas. The five year (fiscal year 2011/12 to 2015/16) average of agriculture contribution in GDP of Nepal is $33 \%$ and the major proportion of population live in rural areas with agriculture as the major source of livelihood. However, a decrease in production and productivity in agriculture due to variability in climate remained a challenge [1]. Climate is affecting Nepalese agriculture system at different levels along the value chain from production, distribution and consumption and appears to have pressure in agrarian livelihood due to low capacity to cope with the changes brought on water, temperature and fragile ecosystems by climate change [2-4].

Climate resilient agricultural practices address food security and climate challenges, integrating three dimensions of sustainable development, namely economic, environmental and social that composed of sustainably increasing productivity, building resilience to climate change and mitigating emissions of greenhouse gases (GHGs) [5,6]. The climate resilience agriculture aims to improve crop production, increase resilience and reduce emissions through the adoption of climate change adaptation and mitigation technologies [5,7]. Vegetable farming can be the best options for climate change adaptation practices at farm level in order to get benefits and reduce the climate risks [8].

The importance of climate resilient farming has increased progressively in Nepal. Government of Nepal (GoN) enacted a 20 year Agricultural Development Strategy (ADS) (2015-2035) which recommends for introducing appropriate adaptation mechanisms to increase resilience of farmers. In order to facilitate the climate resilience agriculture system, GoN has put research and extension services related to climate change adaptation and sustainable agriculture practices in high priority [9]. The ADS has made provision of support packages 
for irrigation, mechanization, value chain development, and export targeting mainly to the commercial farmers.

In this study, climate resilient vegetable practices refers to integrated use of jholmal, compost manure, land preparation techniques, water management and marketing strategy provided by Himalica pilot project through training, regular technical follow- ups, demonstration of technology at farmers' fields, formation of farmers' group \& co-operative, providing market information and material support for farming. From the farmers' perspective, farmers' objective is to maximize earnings of the family [10]. This concept can be turned into reality only after understanding the value chain as the series of activities required to bring a product through various phases of farmers' production to its market destination. This study focused on farmers' production more profitable assisting them with climate resilient agriculture knowledges, along with the market know-how in vegetable farming value chain. So, this study would ultimately enrich the full-fledged value chain in vegetable farming as well as in overall agriculture practices.

\section{Study area}

The study was conducted in three villages namely Bagah

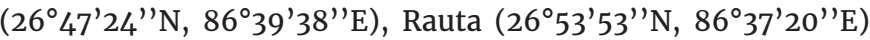
and Saune $\left(26^{\circ} 51^{\prime} 55^{\prime \prime} \mathrm{N}, 86^{\circ} 46^{\prime} 13^{\prime \prime} \mathrm{E}\right)$ representing Terai, foot hill and mid hill areas, respectively, in Udayapur district in Province 1 located in eastern part of Nepal. This district occupies total land area of 206,300 hectare (ha) with $17 \%$ agricultural lands (35,068 ha) of which Bagah, Rautah and Saune covers 3,428 ha, 789 ha and 2,377 ha, respectively, about $44.69 \%$ of agricultural lands with irrigation facilities (DADO Udayapur, 2015/16) [11]. The study sites of Udayapur district links three ecological regions: Mountain (Solukhumbu district), Hills (Khotang, Bhojpur and Okhaldhunga) and Terai (Saptari and Sirahah) of the country with road access.

\section{Methodology}

\section{Sample size and sampling}

The household data were obtained from Himalica pilot project implemented by ICIMOD. The project covered 25 farmers groups (Bagah-10, Rauta- 9 and Saune-6) with 600 households. A half of the project households i.e. 300 households were selected from the study sites (Bagah-150, Rauta-90 and Saune-60) representing the twenty five farmers groups.

The field survey was conducted from August 2017 to February 2018. Firstly, all 25 farmers' groups were purposively chosen in order to select the sample size. Secondly, list of households were obtained from each group that constituted the sampling frame. The household samples of $50 \%$ were obtained from the sampling frame using systematic sampling with random start from each of the twenty five selected farmers' groups. The households selected were interviewed face to face.

\section{Types and sources of data}

Semi-structured questionnaire was used for household survey to collect primary data that included the socio-economic background of the farmers', average annual income from vegetable farming, costs of inputs in vegetable production, selling price of vegetables, and attitude to agriculture practices in overall economic, social and environmental aspects. Similarly, data were collected on climate resilient practices, such as efficient use of water, land preparation techniques, cropping practices, use of compost and bio-pesticides (jholmol). Six FGDs, two in each of the three study areas, were conducted at to get additional information. Key persons including farmers' group representatives, farmers, Junior Technical Assistants (JTA) and members from Himalica project participated in the FGDs.

\section{Data analysis}

The collected data were coded and entered into Microsoft Excel and descriptive statistics such as frequency, percentage and mean were calculated. For the analysis of costs, revenue and profitability, simple accounting method was used. Marketing margins were calculated for different channels of vegetable marketing available for the smallholder farmers in the villages by finding the difference between farmgate price received by the farmers and retail price paid by the consumers for the same product.

\section{Result \& Discussions}

Farmers have been selling their product at farmgate through local traders, local market directly and farmers' cooperatives. Since the local market is small for higher amount of production, farmers opted to sell their produce to major market in district headquarter Gaighat $\left(26^{\circ} 47^{\prime} 20^{\prime \prime} \mathrm{N}, 86^{\circ} 42^{\prime} 27^{\prime \prime} \mathrm{E}\right)$ in Triyuga municipality, Udayapur. To sell the produce directly to Gaighat market is not possible for individual farmers because of small volume of produce, difficulties in transportation, requires high transportation costs, and is time consuming. As a result of active participation of farmers' groups, three co-operatives along with three collection centers (one in each study sites) for vegetables has been established in their villages.

\section{Socio-cconomic characteristics of farmers}

The socio-economic characteristics of the farmers includes household size, age, gender, schooling years and the average annual income. The majority of the household head age group were within the ranges of $30-39$ (32.67\%), 40-49 (30.61\%), and $50-59(31.33 \%)$ and few were in the age group above 70 $(2 \%)$. The gender composition of the household head was 78 percent female headed households and 22 percent of male headed. This distortion is due to outmigration of male members for employment.

Household size is of minimum 1 and maximum 23 members with the mean household size of 5.36 (Table 1) which is much larger than the national average of 4.5. The mean age of household head was 40.28 years and the standard deviation was 11.65. The mean average annual income was of NRs. 76,583 and the farmers' mean school years was found to be five years.

Majority $(90.78 \%)$ of farmers used their own land for farming purposes (Table 2). However, $3.67 \%$ have rented in 
land for farming and $5.33 \%$ both own and rented in land for farming purpose.

\section{Value chain analysis of vegetable farming}

Stages of value chain: Value Chain for this analysis is basically divided into three parts:

\section{Production stage}

2. Collection stage

3. Trading stage

Production stage: The most important stage in the value chain is the production stage. Farmers enter into commercial vegetable farming stage and are motivated to finance more on vegetable production to get return from their produce. Vegetable farming is one of the labor intensive activities and $76 \%$ of cost goes to labor (Figure 1). Farmers produced various types of vegetable on seasonal basis, mainly cole crops, radish, garlic and onion during winter and tomato, cucumber, chili,

Table 1: Socio-economic Characteristics of Farmers.

\begin{tabular}{|c|c|c|c|c|}
\hline Average household Characteristics & Minimum & Maximum & Mean & S.D. \\
\hline Household Size & 1 & 23 & 5.36 & 2.11 \\
\hline Age of head of the farm households & 20 & 74 & 40.28 & 11.65 \\
\hline Average annual income (NRs.) & 50,000 & $5,00,000$ & 76,583 & 57,173 \\
\hline Average Schooling (in years) & 0 & 12 & 5 & 4.50 \\
\hline
\end{tabular}

Source: Field Survey, 2017/18

Table 2: Percent distribution of households by land ownership.

\begin{tabular}{|c|c|c|}
\hline Types of Land ownership & Number of households & Percentage \\
\hline Own land & 272 & 90.78 \\
\hline Rented in land & 11 & 3.67 \\
\hline Rented out land & 1 & 0.33 \\
\hline Both own land \& rented in & 16 & 5.33 \\
\hline Total & 300 & 100 \\
\hline
\end{tabular}

Source: Field Survey, 2017/18

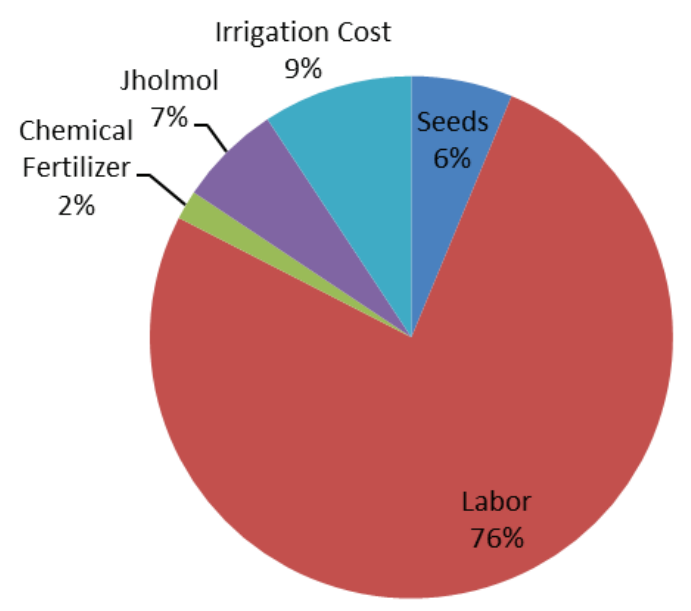

Figure 1: Distribution of costs on inputs used in Vegetable Farming. Source: Based on calculation from field data 2017/18. lady's finger, brinjal and pumpkin during summer, however, the quantity and types of vegetables varies from season to season. The Himalica project provided techniques of vegetable farming through farmers training for efficient use of water, preparation and use of jholmol (a locally made organic pesticides and fertilizer). The Jholmol is widely accepted by the farmers as it is used as bio-pesticides and bio-fertilizer prepared with dung and urine of the livestock. The climate resilient activities imparted to vegetable farming basically include water management, vegetable farming without using chemical pesticides along with reducing chemical fertilizers and increasing compost manure.

Collection stage: Farmers were actively involved in production as well as in marketing. Most of the farmers carried their produce and sold to the local market and some others sell at farmgate. Due to physical contact and through different means of communication to the market, information on price is not a big issue. In case of Bagah, the farmers' cooperative started to collect the vegetables from farmers and charges Rs. 1 per $\mathrm{kg}$ as the service charge ( 1 USD = Rs. 115). According to institutional survey with farmers' group head, it was found that the market price at the farm gate was nearly half of that at the farmers' cooperative. So by establishing farmers' co-operative, they would get a better price for vegetables. By selling at cooperative, the price of vegetable would increase by $60 \%-100 \%$ compared to selling to itinerant traders at the farm gate.

Trading stage: In trading stage of value chain analysis, the main market for these areas was Gaighat town. The demand of the main market (Gaighat) is ever increasing and about $60 \%$ of the total vegetables in this sprawling town is being supplied from India, according to the discussion with local businessman, project officers and farmers cooperatives. So it can be said that, 'there is problem of reaching the market place rather than getting the market price. In case of Bagah, the main market is about of $5 \mathrm{~km}$ from producers and collection center. The collected vegetables were sold at the market on regular basis. In case of Rauta and Saune, which is quite far from Gaighat market i.e. more than $25 \mathrm{~km}$, so large quantity were sold in the local market and some quantity were sent to the Gaighat market. The collection center established by the farmers' groups for the collected vegetables was in early stage during survey period.

\section{Analysis of value chain from farmgate to market}

The agriculture service center initiated by farmers group plays a crucial role in value chain. Farmers sold major portion of their produce to the local market directly (in case of Bagah, local market refers to Gaighat) followed by selling at the farmgate. However, some portion was sold in Gaighat market through farmers' co-operatives, which was started recently during study period in order to systematize the value chain especially for future high production.

Farmers were likely to sell their produce through four selling places i.e. local traders, local market, Gaighat market, and Collection center/co-operative. It was found that $45 \%$ of households sold their product to local market (Table 3). About 
$32 \%$ of total farmers sold to the traders at farmgate/ home. Only $19 \%$ of the households were selling to Gaighat market with the support of farmers' group particularly by arranging transport vehicles for vegetables. Only $4 \%$ were selling through collection center run by co-operatives. The collection centers were newly established during survey time and difficult for offseason vegetable due to low amount of production. However, the awareness of farmers about collection centers for increased production in future shows that produce will be channelized through the collection center.

\section{Role of market structure in vegetable value chain}

Collection centers managed by farmers saving groups have the critical connection in vegetable value chains. In general, collection centers are owned and managed by the farmers, who organize the production and coordinate the marketing of their produce to get suitable price. So, the tendency to sell vegetable through co-operative is increasing and will increase in future along with increase in production. Through bonding relations, smallholders acquire information and gain self-confidence to analyse their own problems and to act collectively [12]. Vegetable farmers were up-to-date with a flow of market price information through different means of communication (SMS from cooperative, radio, television). The condition of symmetrical information with the farmers and traders makes the least difference in price variation.

Only four major vegetables average price (Cauliflower, Cabbage, Cucumber and Tomato) were taken during the survey. Generally, the price of vegetables is influenced by the large/ main market price. In this study, Gaighat is the main market center. According to the flow chart (Figure 2), farmers face three scenarios. In case of traders, they come to the farmers' field and fix the price after negotiation. The farmgate price is determined by intersection of primary supply by the farmers and derived demand of the itinerant traders. The derived demand is based on expected retail price in Gaighat market which is determined by the intersection between the primary demand of the consumers and derived supply of the traders. The difference in price between these two markets determine the marketing margin. In this case, the marketing margin ranges from $66 \%$ to $100 \%$ of the main market retail price and the average price obtained by farmers was found to be Rs.25-30 per kg. Parts of the marketing margin goes to costs of collection, transportation, selling and loss of the products during the process and rest goes to the profit of the traders. In second case, farmers sell their produce in local market at an average of Rs. 45, which is similar to the price in the co-

Table 3: Major Selling points of Vegetables.

\begin{tabular}{|c|c|c|}
\hline Selling Place & No of households & Percentage \\
\hline At farmgate/ home & 97 & 32.33 \\
\hline Local Market & 135 & 45.00 \\
\hline Gaighat market & 57 & 19.00 \\
\hline Farmers' Collection center & 11 & 3.66 \\
\hline Total & 300 & 100 \\
\hline
\end{tabular}

Source: Field Survey, 2017/18

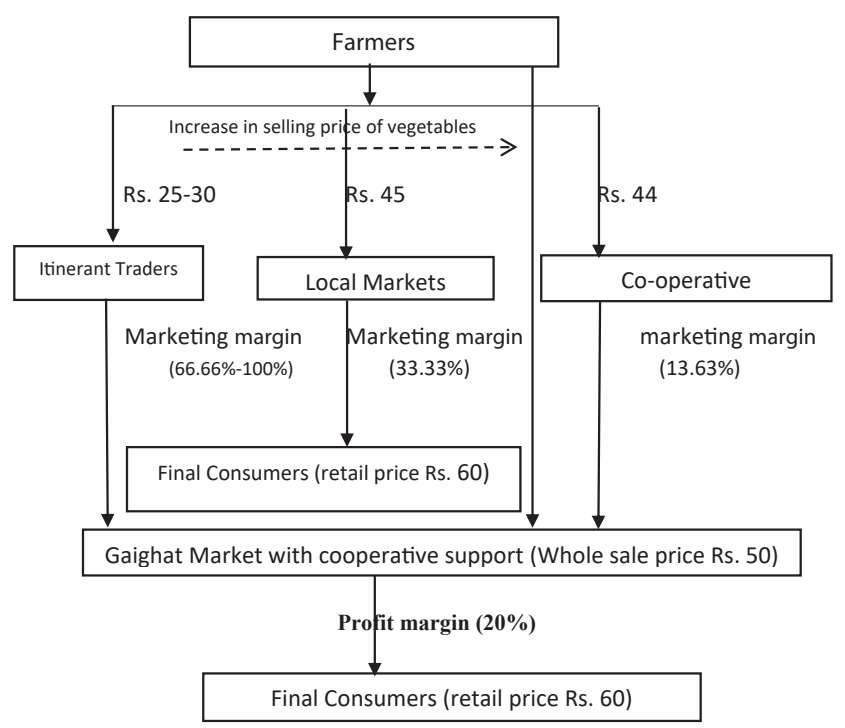

Figure 2: Flow Chart of Vegetable price in different market.

Source: Based on the FGDs and institutional survey 2017/18.

operative. In this case, the marketing margin is $33.33 \%$ with the main market retail price. But, the local market is too small for farmers to expand their produce. In the third case, the farmers sell their produce through co-operatives at an average of Rs. 44 (allocating Rs.1 for service charge). In this case, the marketing margin is $13.63 \%$ with the main market retail price. According to wholesaler and retail traders, their profit margin is around $20 \%$, such that the average retail price faced by consumers was accounted to be Rs. 60 . Therefore, it can be clearly seen that the profit of farmers increases when they sell their produce to farmers' co-operatives or directly to the consumers market. Smaller the marketing margin, more efficient is the marketing channel.

\section{Major challenges in the value chain}

The analysis shows the following major value chain challenges faced by the farmers during the production and marketing of vegetables.

At the stage of vegetable production, water unavailability at farmers' field becomes the major challenge. Nearly half of the farmers told that the lack of irrigation water in their field was the major challenge (Table 4). After that, nearly one fourth revealed pests and diseases are posed as the next major challenge. Another challenge was the poor road access to market, which was mentioned by $17.3 \%$ of the farmers. Other challenges included lack of good quality seeds and no technical support in production process reported by $3.6 \%$ and $5 \%$ farmers respectively. These factors hinder the production level and creating major problems in increasing production level.

\section{Coping strategies for lack of irrigation}

The survey showed the following coping strategies were followed by farmers to overcome water challenges.

Among the 143 farmers reporting the coping strategy, $25.87 \%$ supplied water through pipeline, $24.47 \%$ constructed canal, $19.58 \%$ constructed well and tube well near to their

Citation: Acharya UR, Pant KP (2021) Dynamics of value chain in climate resilient vegetable production practices. J Agric Sc Food Technol 7(1): 067-072. 
vegetable fields, $14.68 \%$ constructed plastic pond, $10.48 \%$ used electric motor pump and $4.89 \%$ constructed water tank at source to solve their water problem (Table 5). In case of farmers from Bagah, majority of farmers used motor pumps and well water for irrigation purpose. In Rauta and Saune, majority of farmers depended on canal water, pipeline supply water, and plastic pond water to overcome the water challenges.

The following activities were recognized by farmers to increase profit in the value chain:

Two-thirds of the farmers viewed that off-seasonal vegetables can fetch higher price than seasonal one in order to increase their profit level (Table 6). However, production of off season vegetable needs higher levels of technical support. Along with seasonal vegetable production, $8.33 \%$ viewed that adopting off-seasonal vegetable farming by using new technology (tunnel construction, drip irrigation, greenhouse installation and mulching) would increase their profit. Finally, along with these activities and improving marketing activities (branding and marketing of organic products, establishing cooperatives, and providing vehicle facilities to access to large markets) would increase the farmers' profit.

Table 4: Major challenges in the value chain of vegetable farming.

\begin{tabular}{|c|c|c|}
\hline Major Challenges & Number of Households & Percentage \\
\hline Lack of irrigation water & 143 & 47.66 \\
\hline Lack of Pests/Diseases management & 79 & 26.33 \\
\hline Poor road access to the market & 52 & 17.33 \\
\hline Lack of close technical supports & 15 & 5.00 \\
\hline Unavailability of good quality seeds & 11 & 3.66 \\
\hline Total & 300 & 100 \\
\hline
\end{tabular}

Source: Field Survey, 2017/18

Table 5: Coping strategies to overcome water challenges in vegetable farming.

\begin{tabular}{|c|c|c|}
\hline $\begin{array}{c}\text { Strategies to overcome water shortage } \\
\text { challenges }\end{array}$ & $\begin{array}{c}\text { Number of } \\
\text { households }\end{array}$ & Percentage \\
\hline Pipeline from water source & 37 & 25.87 \\
\hline Canal construction & 35 & 24.47 \\
\hline Well construction & 28 & 19.58 \\
\hline Plastic pond for rainwater harvesting & 21 & 14.68 \\
\hline Using Motor pump & 15 & 10.48 \\
\hline Constructing Water tank at source & 7 & 4.89 \\
\hline Total & 143 & 100 \\
\hline
\end{tabular}

Source: Field Survey, 2017/18

Table 6: Activities needed to increase profit in value chain.

\begin{tabular}{|c|c|c|}
\hline Activities & Number of households & Percentage \\
\hline $\begin{array}{c}\text { Increase in off-seasonal vegetable } \\
\text { production }\end{array}$ & 201 & 67.00 \\
\hline Adopting new technology & 25 & 8.33 \\
\hline Improvement in marketing activities & 74 & 24.67 \\
\hline Total & 300 & 100 \\
\hline
\end{tabular}

Source: Based on calculation from field survey $2017 / 18$

\section{Social, economic and environmental benefits of Vege- table Farming}

Employment creation: Vegetable farming is a laborintensive process that offers employment in the community particularly for retired persons and women. Vegetable farming would provide the employment for rural unskilled labors and women [13]. Large proportion of households (227 households; $76.95 \%$ ) experienced that farmers leisure time was blatantly cut off after commercial vegetable farming. Before then, most of the farmers spent their leisure time on unproductive activities such as chatting with friends and neighbors, playing cards, and wage labor with low productivity areas. Over $86.78 \%$ of the farmers' income increased after being involved in the vegetable farming.

Increase in saving: Saving has the positive relationship between household and income obtained from vegetable farming. About $70 \%$ of the farmers used to save their income earned from vegetable farming and among them $78 \%$ of the farmers saved their incomes in the co-operatives.

Production in labor shortage: Out of total farmers, $74.24 \%$ didn't use any hired labor in vegetable farming and relied only on their family member for labor force. However, $25.76 \%$ farmers used the hired labor force partially (i.e. only $14 \%$ out of total labor force). The average family labor force used in vegetable farming were two person per household. It shows that vegetable farming can be based on own family even with the shortage of labor in labor market.

Increase in nutrient intake: Vegetables are the vital source of nutrition for health maintenance and prevention of diseases. A minimum level of daily intake of fruits and vegetables except roots and tubers is 400 grams per person i.e. about $150 \mathrm{~kg}$ per person per year [14]. During the study, it was found that almost all of the households consumption of vegetable increased nearly by double after the commercial vegetable farming. Hence, increased consumption of vegetables increases the intake of nutrients.

Active women participation: Women undertake new roles in the society through providing new skills and such skills help in income generation to add to family income [15]. From gender perspective, women were not only involved in production process but also in decision making in vegetable farming activities.

Use of degraded lands: Environmental benefits have been experienced with the use of waste or degraded land with an increase in greenery through vegetable farming. Before vegetable farming people abandoned portion of their land as grazing area and left it without cultivation due to low productivity of traditional crops. During the survey period, it was found that people use fallow land for vegetable production. Among the practices one of them is degraded land management, which provides positive opportunities and support to adapt in changing climate for the mountain people $[16,17]$. More than a half of the total respondents (158 households) answered that they used fallow land for vegetable farming. The average size 
of fallow land used per household was of 0.08 hectare $(1.58$ ropani).

\section{Conclusions and Recommendations}

The climate resilient vegetable production is profitable for farmers and also provide nutrition to the family members. The vegetable farming has become an additional income source for the households and improved the required dietary necessities of the family members after the implementation of climate resilient agriculture project. However, the value chain analysis shows that profit of the farmers depends on the market type they access, as farmers' revenue increases when they sell their produce either directly to the local market or through farmers' collection center managed by farmers' co-operatives. Farmers need irrigation water, material supports, technology and the most important factor is the formation of farmers' group to increase the profit. These supports help the farmers to mitigate the risk from climate change and climate variability leading them to climate resilient farming. Vegetable farming has resulted in the employment creation and income generation at the local level. The climate resilient vegetable practices enables the vegetable farming in the irrigated land as well as in the waste land. So, vegetable farming delivers not only employment as economic benefit but also environmental benefit. Additionally, the vegetable farming increases the social cohesion through co-operation, and sharing of knowledge on vegetable farming processes. A climate resilient practice in vegetable farming plays a significant role in the standard of living of farmers and vegetable consumption reduces the problem of food insecurity. This shows that besides economic benefits of vegetable farming, there are several positive externalities of environmental and social benefits. This research can be extended to determine the farmers' willingness to pay for the training and assistances in climate resilient agriculture practices, which was provided free of cost by Himalica project in this study.

The value chain of vegetable farming includes production stage and marketing stage, which indicates that farmers require initial support in terms of knowledge regarding formation of farmers groups and cooperative in order to enhance value chain in vegetable farming. Similarly, providing knowledge on climate resilient agriculture practices for off-season vegetables will encourage the small holder's to commercial farming, which is useful to stabilize and strengthen the vegetable value chain. Hence, it is evident that climate resilient agriculture practices needs to be implemented from the government level to reach farmers' level with the intention of enhancing sustainable agriculture system in the country.

\section{References}

1. MOF (2016) Economic survey 2015/16. Kathmandu, Government of Nepal: Ministry of Finance.
2. Adhikari J (2012) Agriculture adaptation practices in South Asia: Case of Nepal. Kathmandu: South Asian Watch on Trade. Economics and Environment (SAWTEE). Link: https://bit.ly/3u9AE6i

3. Pant KP (2012) Climate change and food security in Nepal.The Journal of Agriculture and Environment 13: 9-19. Link: https://bit.ly/3badLa8

4. Pokhrel DM, Pandey B (2011) Climate change adaptation: Strategic vision in agriculture. The Journal of Agriculture and Environment 12: 104-112. Link: https://bit.ly/3s21jjg

5. FAO (2013) Smallholder integration in changing food markets. Food and Agriculture Organization of the United Nations, Rome. Link: https://bit.ly/3bbxrKA

6. Behnassi MB (2014) Achieving food security in a changing climate: the potential of climate-smart agriculture. In S. S. Ahmed (ed.), Environmental cost and face of agriculture in the Gulf cooperation council countries: Fostering agriculture in the context of climate change, (pp. 27-42). Gulf Research Centre Cambridge.

7. Paudel B, Khanal RKC, Bhatta AK, Chaudhary P (2017) Climate-smart agriculture in Nepal: Champion technologies and their pathways for scaling up. Climate-smart agriculture in Nepal: Policy Brief. Link: https://bit.ly/3puk798

8. Ali A, Erenstein O (2017) Assessing farmer use of climate change adaptation practices and impacts on food security and poverty in Pakistan.Climate Risk Management 183-194. Link: https://bit.ly/3qut2ZN

9. MOAD (2014) Agricultural development strategy (ADS). Ministry of Agriculture and Development, Singadurbar, Kathmandu: Ministry of Agricultural Development. Link: https://bit.ly/2ZohB9X

10. Gittinger JP (1982) Economic analysis of agricultural projects. Baltimore: Published for The Economic Development Institute of the World Bank by Johns Hopkins University Press. Link: https://bit.ly/2Nhpxau

11. DADO,Udayapur (2016) Agricultural statictical details and district profile (2015/16). District Agriculture Development office:Udayapur, Gaighat, Government of Nepal (in nepali version).

12. FAO (2013) Climate-smart agriculture source book. Food and agriculture organization of the united nations. Link: https://bit.ly/3ap8nAH

13. Husnain MI, Khan M (2015) The public and private benefits from organic farming in Pakistan. SANDEE. Working Paper No 99-15, 1-25. Link: https://bit.ly/3bbYGF0

14. WHO (2003) Diet, nutrition and the prevention of chronic diseases: report of a joint WHO/FAO expert consultation. Geneva: World Health Organization. Link: https://bit.ly/3s1B0tH

15. Sharma M (2017) Women empowerment through value addition in agricultural produce. International Journal of Home Science 3: 163-166. Link: https://bit.ly/2Nhp34a

16. Pratap T (2011) Hill Agriculture: Challenges and Opportunities. Ind J Agri Econ 66. Link: https://bit.ly/3k3MkTq

17. MOAD (2014) Agricultural development strategy (ADS). Ministry of Agriculture and Development, Singadurbar, Kathmandu: Ministry of Agricultural Development. Link: https://bit.ly/37oyC8p 